\author{
Kulinchenko, O.S. ${ }^{1}$, and Vainola, R.Kh. ${ }^{2}$ \\ ${ }^{1}$ State University of Infrastructure and Technology, \\ 9, Kyrylivska St., Kyiv, 04071, Ukraine, \\ +380 44463 7470, +380 67507 3093, kulinchenkooleksandr@gmail.com \\ ${ }^{2}$ Dragomanov National Pedagogical University, \\ 9, Pyrohov St., Kyiv, 01601, Ukraine, \\ +380 9734489 48, vainola@ukr.net

\section{CHARACTERISTICS OF THE EXPERIMENTAL STUDY ON ASSESSING THE LEVELS OF PROFICIENCY OF STUDENT SOCIAL ACTIVITY IN CONDITIONS OF HIGHER EDUCATION INSTITUTION}

Introduction. Nowadays, student self-government is one of the effective forms of student self-organization; it appears to be the mechanism of representing and protecting students' rights. It is the factor of self-realization and development of social activity in conditions of higher education institution.

Problem Statement. The formation of student social activity is a problem of modern pedagogy, since it requires the development of technologies for participating in socially significant activities within the social environment of higher education institutions.

Purpose. To characterize and to analyze the stages of the pedagogical experiment regarding the state of the students' proficiency in terms of social activity.

Materials and Methods. A series of diagnostic methods has been used: overt observation, surveys (polls), testing, ranking, moderation method, method of independent expert assessments, a modified version of E. Shakirova's methodology for diagnosing student social activity, and V. Yadov's methods.

Results. The stages of the assessment of the levels of the formation of student social activity as well as their indicators and criteria have been characterized and analyzed; the socio-pedagogical conditions for the formation of student social activity within the self-government bodies of a higher education institution have been determined: the creation of the structure and bodies of student self-government alongside with the ensuring of the representation of each student groups; the organization of student self-government activities in various fields (organizational, public, research-oriented, physical culture and health-targeted, artistic, creative, educational, informational, and volunteering); the self-organization of students' life and their involvement into various forms of work performed by self-government bodies; the involvement of teachers into the work of student self-government and promotion of step-by-step formation of student social activity.

Conclusions. Currently, students are considered to be not only an intellectual and demographic, but also a spiritual resource of our country. Therefore, social and pedagogical support for the formation and development of indicators of student social activity is a priority task of social and educational work of higher education institutions.

Keywords: social activity, formation of student social activity, and student self-government.

At the current stage of the strategic renewal of the national educational policy, the issue concerning the formation within a new framework of a citizen who is creative and capable to get actively (c) KULINCHENKO, O.S., and VAINOLA, R.Kh., 2019 engaged in various spheres of public life becomes particularly relevant. Higher education institution plays a special role in the formation of such a person, where the future of the nation, its social and cultural gene pool is formed based on huma- 
nism and democratization. Students appear to be now not only an intellectual or demographic, but also a spiritual resource of our country. Therefore, socio-pedagogical support for the formation and development of the indicators demonstrating student social activity is now a priority task of any social and educational research. At the same time, the recognition of students' role as an active subject of social processes requires a detailed elaboration of the aspects enabling the formation of student social activity and their participation in the activities of self-government bodies, in particular.

Theoretical and methodological principles used while studying the problem of formation of student social activity are as follows: the identification of the mechanisms of student socialization within extra-curricular activities [1]; research on the integration of educational social impacts of the society in shaping the sense of nationhood of youth [2]. In the theory of social pedagogy, various aspects related to the formation of student social activity are reflected in these aspects: the identification of socio-pedagogical conditions for the development of the leadership potential of student bodies at universities [3]; the implementation of the characteristics of student self-government as a means of youth socialization [4]; the identification of socio-pedagogical conditions of student selfgovernment organizations in higher educational institutions [5].

The theoretical and methodological analysis of scholarly research literature has made it possible to conclude that the level of theoretical study of the problems concerning the formation of student social activity under conditions of the activity of selfgovernment bodies is insufficient. At the same time, there has not been found any sufficient practical solution of the given problem in the system of educational work of higher education institutions.

The aim of this research is to characterize and to analyze the stages of experimental work and to assess the formation of student social activity. Addressing the tasks facilitates achieving the aim: 1) to disclose the scholarly research principles of the formation of student social activity under con- ditions of the self-government bodies at higher educational institutions; 2) to specify the content of the basic concepts "social activity", "student self-government" as interconnected ones; 3) to identify the criteria, indicators, and the formation levels of student social activity under conditions of the self-government bodies operating in higher educational institutions; 4) to identify the socio-pedagogical conditions for the formation of student social activity within the activities of self-government bodies operating in higher education institutions.

In 2016-2018, we developed and implemented an experimental study that included the elaboration of the list of qualities that characterize a student as a socially active person; the determination of levels of formation of student social activity; and the substantiation of social and pedagogical conditions facilitating the formation of student social activity.

Based on the analysis of scholarly research, the criteria for the formation of student social activity have been presented and their indicators have been defined: the cognitive (awareness of the need for knowledge which proves to be essential for life success; knowledge of social reality; knowledge of behavioral modes in social and educational situations; cognitive thinking); the motivational and emotional (social responsibility; attitude to work and to education; empathy and emotional stability; moral and ethical culture; attitude to universal values); the ideological (social attitudes: readiness for perception and assessment of social phenomena; objectivity, self-sufficiency and independence in judgments; the formation of universal and professional values; readiness for addressing life and professional situations; adoption of social benefits); and the behavioral (manifestations of social and civil positions; conscious choice of socio-ethical norms of behavior; participation in the activities of self-government bodies in higher education institutions; initiative and creative attitude towards socially useful work).

The indicated criteria and indicators have allowed us to determine the levels of formation 
(proficiency levels) of student social activity (optimal, sufficient, intermediate, and insufficient) and to characterize them.

The optimal level is characterized by the presence of profound knowledge of socially significant values, social reality, broad social and personal interests reflecting social motives; ways of optimal behavior in different life and social educational situations. These students have a stable system of beliefs, humanistic and moral orientations; they demonstrate a conscious choice of social and ethical norms of behavior. The students who demonstrate an optimal level of social activity have a high level of social culture, a positive attitude to surroundings. Social responsibility and a positive attitude to learning, social activities are typical of this category of students; they regularly perform socially valuable deeds. The students are independent in their own judgment; possess an active life position, which testifies to person's conscious attitude to his / her life; they make a conscious choice of direction, forms and various types of activities within student selfgovernment, strive for creative achievements and generate initiatives.

The sufficient level implies that the students have knowledge about social values, social reality, the ability to identify the best ways of behavior in different life and educational social situations; the students demonstrating the specified level are characterized by a stable positive attitude towards activities within self-government bodies; they are aware of the ways how they can solve their tasks, make independent evaluative judgments, which sometimes depend on the situation. There is a situational display of indicators of social activity. The students constituting this group get usually willingly involved into various types of socially positive activities, though sometimes it occurs under the external influence of teachers, circumstances. These students support other student initiative, but they often act according to some model, at the level of reproduction.

The intermediate proficiency level of social activity is characterized by a certain amount of know- ledge about socially significant values, social reality; the ability to demonstrate the best ways of behavior in different life and social-educational situations. The students of the specified level demonstrate unstable manifestation of social responsibility and positive attitude to participation in self-government bodies and public organizations, dependence on other people's opinion. They make and independent evaluation judgments only for the purpose of self-affirmation; they are characterized by an unstable social position; while participating in extra-curricular social and educational activities, they demonstrate instability of interests, orientations towards adaptability in the social and educational spheres.

The insufficient proficiency level of student social activity is characterized by a non-systemic nature of knowledge about socially significant values, social reality; the students feel difficulties in mastering the abilities to find the optimal ways of behavior in different life and social-educational situations. They are characterized by: an unstable level of social culture and a positive attitude to surroundings; unstable manifestation of social responsibility and a positive attitude to participation in self-government. These students have an insufficiently stable social position, they depend on the thought of the reference group and ignore public orders. An unstable attitude and manifestation of external motivation to socially useful activity (with one-time participation in it) are typical of this category of students. There is a tendency to display negative behavior.

To assess the formation levels of student social activity, the following diagnostic methods and techniques were used: observation, questioning, testing, ranking, method of moderation, method of independent expert evaluations, modified version of the diagnostics of student social activity elaborated by O. Shakirova, V. Yadov's methods, etc. The aggregate coefficient of the formation of student social activity was determined by means of the formula $K=(O+2 / 3 D+1 / 3 C): Q[6]$, where: $O-$ the sum of the points representing manifestation of the indicators at the optimal le- 
vel; $D$ - the sum of the points representing manifestation of the indicators at the sufficient level; $C$ - the sum of the points representing manifestation of the indicators at the intermediate level; $Q-$ the number of indicators. Such an approach allowed us to introduce a scale of levels with the help of which the manifestations of the students' proficiency in social activity were evaluated, as follows: $0 \leq K \leq 0.24-$ the insufficient level; $0.25 \leq K \leq 0.50$ - the intermediate level; $0.51 \leq K \leq 0.75$ - the sufficient level; $0.76 \leq K \leq 1.0$ the optimal level.

As a result of the theoretical analysis of scientific literature the concept of the creative nature of the development of the social activity in which the person is viewed through the prism of his / her interaction with the environment is taken as the basis; whereas the involvement of an individual into society implies the activity of an individual, his / her initiative, his / her ability to independently choose a line of conduct, to govern his / her actions. We base our study on the assumption that a social activity incorporates actual needs of an individual, realized in a particular system of target settings, motives reflecting individual's interests. Social activity [7] is defined as an integrative property of a person characterized by his / her desire and inner readiness for active society-centered actions which are determined by socially valuable motives, realized in the initiative, creative socially significant activity grounded on the principles of subjectivity and self-management.

The process aimed at the formation of student social activity is considered as a condition and a result of a dynamic process providing gradual acquisition of the signs of social proficiency, necessary professional and personal qualities through the assimilation of social experience and participation in socially significant activities in the social environment of a higher education institution.

Student self-government is interpreted as a form of student self-organization, the mechanism of representation and defense of their rights, which provides the possibility of their self-reali- zation and development of the social activity in institutions of higher education; it is determined by the right and real ability of the student community to independently solve issues within the framework of the current legislation and the statute of higher education institution.

Self-government bodies are defined as various concrete forms of student self-organization which manifest themselves as a real embodiment of selfgoverning tendencies in a student's environment.

According to the results of the theoretical analysis of the designated issue, we set this task: to find out the real state of students' proficiency in social activity under conditions of the self-government bodies.

545 second-, third- and fourth-year students from three higher education institutions of Ukraine were included in various forms of pedagogical diagnostics: Drohobych Ivan Franko State Pedagogical University (specialty "Social Pedagogy"), Kyiv State Maritime Academy named after hetman Petro Konashevich-Sahaydachniy (specialty "Navigation") and Kherson State University (specialty "Culture Studies").

The method of ranking students' answers (selfassessment) allowed us to determine the qualities that characterize a student as a socially active person. It was found that they include: initiative, purposefulness, persistence, autonomy, creative attitude, organization, sociability, justice, tolerance, and adherence to principles which are necessary for socially meaningful activities. There were identified these formation / proficiency levels of the mentioned qualities: insufficient - 98 students (20.92\%) and intermediate - 109 (23.9\%). The least developed were the qualities, as follows: adherence to principles, tolerance, justice, sociability and organization.

We have applied a modified version of the methodology for diagnosing the student social activity in the pedagogical college [7]. In this case, the components of their social activity were evaluated by means of a five-point scale. The points correspond to certain manifestation levels of a particular indicator: 5 - the indicator is mani- 
fested continuously, clearly; it is typical of an individual; 4 - the indicator more often manifests itself than otherwise; 3 - the indicator is not sufficiently manifested; 2 - the indicator appears more often in contrast to the specified indicator of the social activity; 1 - the opposite indicator manifests itself expressively and actively (Table 1). It should be noted that the expert assessments of social qualities made by teachers are somewhat different from the student self-assessment. This is especially noticeable while assessing such qualities as "targeting" and "independence", which were lower due to student self-assessment. Undoubtedly, the proficiency level of these qualities changes in the process of intensive growth of student social experience and the deepening of their specific knowledge, which, in turn, contributes to the development of students' motivation and positive attitude to the social activity as a quality and a phenomenon.

At the next stage, we invited students to express their vision on the indicators representing each criterion of the social activity: cognitive, motivational, emotional, ideological, activity- and behavior-centered. For this purpose, we have applied a modified version of the method elaborated by V. Yadov [8]. According to the instructions of this method, students are informed of how to perform assignments, a table with the specified indicators is added. A synthesis of the results was carried out by a group of independent experts. As the manifestation of these or other indicators, experts could assess the students' outcomes by means of the grade point average in accordance with the content characteristics of each point given in the instructional part. This allowed us to get an idea of a generalized assessment of each student's social activity. The analysis of the results shows that more than 33.1\% (144 persons) of the students failed to describe the identified components, only 18\% (78 persons) could name certain qualities - signs for each criterion. In particular, it concerns the information about cognitive and ideological criteria. The activitycentered criterion caused the least difficulty: about $49 \%$ (213 respondents) of the students called the activities which could be referred to the social activity.

In general, students' responses displayed their understanding of the meaning of the concept "social activity" as well as the peculiarities of its manifestation. We used the method of moderation which has been known in educational technology since the 1960's when dealing with the first- and second-year students: 51 students from Kyiv State Maritime Academy named after hetman Petro Konashevich-Sahaydachniy, 54 students from Kherson State University and 57 students from Drohobych Ivan Franko State Pedagogical University. It should be noted that the students of two educational institutions major in different specialties, whereas the tasks were identical, to be more precise:

+ to understand how fully students comprehend the meaning of the concept "social activity of an individual" and "student social activity";

+ to find out if the students can identify those indicators (criteria) of the social activity, the formation of which cannot be traced during their training;

Table 1

Comparative Table of Self-Assessment

of Qualities that Contribute to the Formation of the Social Activity

\begin{tabular}{|c|l|c|c|}
\hline \multirow{2}{*}{$\begin{array}{c}\text { Want to } \\
\text { possess }\end{array}$} & \multicolumn{1}{|c|}{ Qualities } & \multicolumn{2}{|c|}{ Possess, grade point average } \\
\cline { 3 - 4 } & & $\begin{array}{c}\text { Expert } \\
\text { assessment }\end{array}$ & $\begin{array}{c}\text { Self- } \\
\text { assessment }\end{array}$ \\
\hline 4.9 & Initiative & 4.72 & 4.02 \\
4.82 & Targeting & 4.56 & 3.92 \\
4.52 & Persistence & 4.32 & 4.15 \\
4.84 & Independence & 4.02 & 3.62 \\
4.91 & Creative attitude to & 3.8 & 4.32 \\
4.86 & activity & 3.72 & 4.52 \\
4.36 & Organization & 3.65 & 3.7 \\
4.73 & Communication skills & 3.56 & 4.23 \\
4.53 & Justice & 3.53 & 3.92 \\
4.02 & Tolerance & 3.26 & 3.61 \\
& principles & & \\
\hline
\end{tabular}


+ to identify the students' abilities to understand the potential of social activity development.

According to the results of the moderation method, we found out: there is a fairly large variety of definitions of the concept "social activity of an individual". The most typical answers were these ones: "participation in public life", "activity for the benefit of others", "relationship with society", "self-expression”, etc. It was revealed that $32(59.23 \%)$ persons out of 54 students of Kherson University, 39 students (63.2\%) out of 57 students of Drohobych University and 36 persons (71.1\%) out of 51 students of Kiev Academy of Water Transport equate the essence of the concept "social activity" with the meaning of selfexpression, social activity and self-realization. About $40 \%$ of the Academy of Water Transport students, $29 \%$ of the Kherson University students and 35\% of the Drohobych University students were unable to provide an approximate understanding of the concept "social activity".

At the next lessons, the experts and authors of the research personally conducted educational classes and diagnostic conversations aimed at clarifying the concept "social activity". According to the results of the diagnostic interviews, assessment of the contents of the students' responses, it was possible to conclude that the students not only began to understand the essence of the basic concepts, but also to distinguish possible forms of manifestation of the social activity. In determining the forms of the social activity, the students enlisted its types: professional activity (Kherson - 28, Drohobych - 23, Kyiv 31 persons), participation in public and youth organizations respectively (Kherson - 30, Drohobych -33 , Kyiv - 29 persons), participation in management of a group within a university community, respectively (Kherson - 21, Drohobych 27 , Kyiv -29 persons), assistance and support of others respectively (Kherson - 18, Drohobych 21 , Kyiv -23 persons). It has been established that, in general, up to $50 \%$ of the students have somewhat focused on the types and forms in which the social activity may be manifested.
This stage of work contributed to the students' independent search for possible means enabling the formation of the social activity while studying at a higher education institution. In general, the participants of the experiment focused on various forms of extra-curricular social and educational activities, to which they included: participation in community activities, clubs, circles, targeted socially significant activities, collective cooperation, etc. During the conversations, the students concluded that the social activity as a phenomenon depends both on self-education and on the content of social and educational activities in a higher educational institution. According to the students' comments, the most productive means of forming social activity in higher education is the involvement in various types of targeted activities. This is quite logical, since students (aged 18-20) state their position as a possible transformation of the motive into the action, they are less inclined to analytics, to evaluation of the social activity. Obviously, this can be explained by the lack of awareness of the specific content characterizing the social activity and the lack of motivation or interest. Therefore, the students of the experimental and control groups were invited to name the possibility of how project activities and initiative activities (at the choice) might be included into targeted sociopedagogical situations at extra-curricular time.

In order to analyze the effectiveness of using the moderation method, we attempted to reduce the characteristics of the social activity given by the students, their perception of "social activity of an individual" and "social activity of a student".

The analysis of the results allowed us to assert that more than $33.1 \%$ (144 persons) of the students failed to characterize the indicated components, only $18 \%$ (78 people) could name certain qualities - indicators of each criterion. In particular, it concerns the information about the cognitive and ideological criteria. The activity-centered criterion caused the least difficulty: about $49 \%$ (213 respondents) of the students called the activities which could be referred to the social activity. 
At the next stage of the work we considered it expedient to find out exactly which forms of socially significant activity respondents prefer. The answers of 435 students were distributed in the following way (in quantitative rank):

+ participation in group and institute events (199 people);

+ participation in self-management at different levels (112 people);

+ participation in artistic and creative activities (136 people);

+ participation in public activities (81 people);

+ participation in volunteering activities (98 people);

+ other activities (96 people).

According to the survey conducted, the students' orientation towards the established forms of social work was noticeable, although in the technical higher educational institution (Kyiv) students showed a greater tendency to participate in academic activities; in the humanities (Kherson, Drohobych) - in artistic-applied and volunteering activities. In general, the quantitative indicators demonstrated the students' willingness to participate in various types of social, socially significant activities. However, students' answers did not reveal the role and place of selfgovernment as a factor facilitating the development of their social activity.

According to the results of this stage of the work, an experimental group was constituted from the students of Kyiv State Maritime Academy named after hetman Petro Konashevich-Sahaydachniy (211 people); 224 students of Drohobych Ivan Franko State Pedagogical University were enrolled in the control group. The conducted questionnaires, expert evaluation, methods of selfassessment allowed us to determine the real proficiency level of the student social activity according to four criteria as well as their reflection in the indicators (Table 2).

It has been established that a significant part of the students demonstrated the insufficient level of the social activity (CG - 32.59\% and EG $27.1 \%)$. At the intermediate level, the rates range from $41.52 \%$ to $45.5 \%$ (for CG and EG). A small percentage of the students demonstrated the sufficient proficiency level according to the indicators of the social activity ( $\mathrm{CG}-16.52 \%$ and $\mathrm{EG}-$ $18.48 \%$ ). Only $9.37 \%$ of the students constituting the CG and $9.01 \%$ of the students representing the EG have the optimal level. The obtained data stipulated the need to improve the activities of student self-government bodies in terms of the formation of their social activity, which provided the choice of forms and methods for further experimental work.

The evaluation of the results of the experimental work, generalization of theoretical approaches $[9 ; 10]$ on creating conditions for self-realization of a person in social institutions allowed us to determine the socio-pedagogical conditions facilitating the formation of student social activity under conditions of self-government bodies: creation of the structure and bodies of student selfgovernment alongside with the ensuring of the representation of each student groups; organization of student self-government activities in various fields of activity (organizational, public, research-oriented, physical culture and healthtargeted, artistic-creative, educational-informational and volunteering); self-organization of students' livelihoods and their involvement into various forms of work performed by self-government bodies; the involvement of teachers into the work of student self-government and promotion of step-by-step formation of student social activity.

Table 2

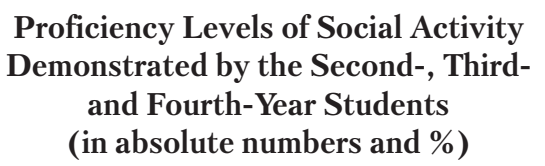

\begin{tabular}{|l|c|c|c|c|}
\hline \multirow{2}{*}{ Levels } & \multicolumn{2}{|c|}{$\begin{array}{c}\text { Experimental group } \\
\text { (EG) - 211 persons }\end{array}$} & $\begin{array}{c}\text { Control group (CG ) - } \\
\text { 224 persons }\end{array}$ \\
\cline { 2 - 5 } & $\begin{array}{c}\text { Absolute } \\
\text { numbers }\end{array}$ & $\%$ & $\begin{array}{c}\text { Absolute } \\
\text { numbers }\end{array}$ & $\%$ \\
\hline Optimal & 19 & 9.0 & 21 & 9.4 \\
Sufficient & 39 & 18.48 & 37 & 16.0 \\
Satisfactory & 96 & 45.6 & 93 & 41.5 \\
Insufficient & 57 & 27.1 & 73 & 32.6 \\
\hline
\end{tabular}


The theoretical analysis of the issues regarding the formation of student social activity under conditions of self-government activities carried out by us as well as the experimental research conducted have made it possible to confirm the existence of significant shortcomings in the socio-educational work of higher education institutions in terms of the formation of student social activity, the lack of a system of work in the area of student self-government bodies. That is why we have identified prospects for further scientific research: verification of the effectiveness of certain socio-pedagogical conditions for the formation of student social activity within the activities of self-government bodies; definition of the most effective forms and methods of students' involvement into the activities of self-government bodies in order to develop their social activity; determination of the relationship between the formation process of student social activity and their professional and personal growth.

\title{
REFERENCES
}

1. Savchenko, S. V. (2003). Scientific and theoretical principles of socialization of student youth in extracurricular activities under conditions of regional educational space. Luhansk: Alma Mater [in Ukrainian].

2. Savrasova-Viun, T. O., \& Chernukha, N. M. (2014). Students' civic activity: psychological characteristics of developmental manifestations. Educology: Ukrainian-Polish Yearbook, 3, 122-125 [in Ukrainian].

3. Volkivska, D. A. (2016). Socio-pedagogical conditions for developing the leadership potential of the university students' active. Collection of scientific papers Kamianets-Podilskyi National Ivan Ohiienko University. Pedagogical Series, 26, 27-36. URL: http://nbuv.gov.ua/UJRN/znpkp_sp_2016_26_5) [in Ukrainian].

4. Sheina, L. O. (2010). Students'self-government as a way of youth's socialization. PhD (Ped.) Luhansk [in Ukrainian].

5. Vainola, R. Kh. (2008). Personal development of the future social pedagogue in the process of professional training. S. O. Sysoieva (Ed.). Zaporizhzhia: KhNRBTs [in Ukrainian].

6. Sysoieva, S. O., \& Krystopchuk, T. Ye. (2009). Pedagogical experiment in scientific studies of continuous professional education. Lutsk: VAT "Volyn Regional Printing House" [in Ukrainian].

7. Shakirova, E. F. (2010). The formation of the social activity of the students studying a at pedagogical college in extracurricular activities. PhD (Ped.) Moscow [in Russian].

8. Yadov, V. A. (1995). Social and socio-pedagogical mechanisms for the formation of person's social identity. Russia's World, 3-4(5), 158-182 [in Russian].

9. Sopivnyk, R. V. (2003). Educational function of students' self-government bodies. Problems of Ukrainian history: facts, judgments, searches, 2, 168-173 [in Ukrainian].

10. Potopa, K. L. (2006). Socio-pedagogical conditions for organizing students' self-government in higher educational establishments. PhD (Ped.) Kyiv [in Ukrainian].

Стаття надійшла до редакції / Received 12.10.18

Статтю прорецензовано / Revised 07.11.18

Статтю підписано до друку / Accepted 21.11.18

\author{
О.С. Кулінченко ${ }^{1}$ Р.Х. Вайнола ${ }^{2}$ \\ ${ }^{1}$ Державний університет інфраструктури і технологій, \\ вул. Кирилівська, 9, Київ, 04071, Україна, \\ +380 44463 7470, +380 67507 3093, kulinchenkooleksandr@gmail.com \\ ${ }^{2}$ Національний педагогічний університет імені М.П. Драгоманова, \\ вул. Пирогова, 9, Київ, 01601, Україна, \\ +380973448948, vainola@ukr.net
}

\section{ХАРАКТЕРИСТИКА ЕКСПЕРИМЕНТАЛЬНОЇ РОБОТИ \\ З ВИЯВЛЕННЯ РІВНЯ СФОРМОВАНОСТІ СОЦІАЛЬНОЇ АКТИВНОСТІ \\ СТУДЕНТІВ В УМОВАХ ЗАКЛАДУ ВИЩОЇ ОСВІТИ}

Вступ. Студентське самоврядування на сьогодні є однією з найбільш дієвих форм самоорганізації студентів, що виступає механізмом представництва та відстоювання прав студентів, чинником самореалізації та розвитку соціальної активності в умовах закладу вищої освіти. 
Проблематика. Формування соціальної активності студентів є проблемою сучасної педагогіки, оскільки потребує розробки технологій участі в суспільно значущій діяльності в соціальному середовищі закладу вищої освіти.

Мета. Здійснити характеристику та аналіз етапів експериментальної роботи з оцінки стану сформованості соціальної активності студентів.

Матеріали й методи. Застосовано методи включеного спостереження, опитування, тестування, ранжування, метод модерації, метод незалежних експертних оцінок, методику діагностики соціальної активності студентів Е. Шакірової, методику В. Ядова.

Результати. Проаналізовано та охарактеризовано етапи педагогічної оцінки рівнів сформованості показників і критеріїв соціальної активності студентів. Визначено соціально-педагогічні умови формування соціальної активності студентів: створення структури й органів студентського самоврядування та забезпечення представництва кожної студентської групи, організація діяльності студентського самоврядування з різних напрямків діяльності; самоорганізація життєдіяльності студентів, залучення їх до різних форм роботи органів самоврядування, включення педагогів у роботу студентського самоврядування, їх сприяння поетапному формуванню соціальної активності студентів.

Висновки. Студенти на сьогодні виступають не лише інтелектуальним та демографічним, а й духовним ресурсом нашої країни. Тому соціально-педагогічна підтримка формування та розвитку показників соціальної активності студентства є пріоритетним завданням соціально-виховної роботи закладу вищої освіти.

Ключові слова: соціальна активність, формування соціальної активності студентів, студентське самоврядування.

\author{
А.С. Кулинченко ${ }^{1}$, Р. Х. Вайнола \\ ${ }^{1}$ Государственный университет инфраструктуры и технологий, \\ ул. Кирилловская, 9, Киев, 04071, Украина, \\ +380 $444637470,+38067507$ 3093, kulinchenkooleksandr@gmail.com \\ ${ }^{2}$ Национальный педагогический университет имени М. П. Драгоманова, \\ ул. Пирогова, 9, Киев, 01601, Украина, \\ +380973448948, vainola@ukr.net

\section{ХАРАКТЕРИСТИКА ЭКСПЕРИМЕНТАЛЬНОЙ РАБОТЫ ПО ВЫЯВЛЕНИЮ УРОВНЯ СФОРМИРОВАННОСТИ СОЦИАЛЬНОЙ АКТИВНОСТИ СТУДЕНТОВ В УСЛОВИЯХ ВЫСШЕГО УЧЕБНОГО ЗАВЕДЕНИЯ}

Введение. Студенческое самоуправление в настоящее время является одной из наиболее действенных форм самоорганизации студентов, выступает механизмом представления и отстаивания прав студентов, фактором самореализации и развития социальной активности в условиях учреждения высшего образования.

Проблематика. Формирование социальной активности студентов является проблемой современной педагогики, поскольку требует разработки технологий участия в общественнозначимой деятельности в социальной среде учреждения высшего образования.

Цель. Анализ и характеристика этапов экспериментальной работы по оценке состояния сформированности социальной активности студентов.

Материалы и методы. Использованы методы включенного наблюдения, опросы, тестирование, ранжирование, метод модерации, метод независимых экспертных оценок, методика диагностики социальной активности студентов Э. Шакировой, методика В. Ядова.

Результаты. Проанализированы и охарактеризованы этапы педагогической оценки уровней сформированности, показателей и критериев социальной активности студентов. Определены социально-педагогические условия формирования социальной активности студентов: создание структуры и органов студенческого самоуправления и обеспечение представительства каждой студенческой группы, организация деятельности студенческого самоуправления по различным направлениям деятельности, самоорганизация жизнедеятельности студентов, вовлечение их в различные формы работы органов самоуправления, включение педагогов в работу студенческого самоуправления, их содействие поэтапному формированию социальной активности студентов.

Выводы. Студенты в настоящее время выступают не только интеллектуальным и демографическим, но и духовным ресурсом нашей страны. Поэтому социально-педагогическая поддержка формирования и развития показателей социальной активности студенчества является приоритетной задачей социально-воспитательной работы учреждения высшего образования.

Ключевые слова: социальная активность, формирование социальной активности студентов, студенческое самоуправление. 